\title{
31. The Meaning of International Constitutional Law
}

\author{
Bardo Fassbender
}

\section{Two Faces of a Problem: Sovereignty and Constitutionalism in International Law}

At the end of an article about the concept of sovereignty in international law, ${ }^{1} \mathrm{I}$ quoted Hans Kelsen and Wolfgang Friedmann. In spite of all their differences, both scholars were strong supporters of an international constitutional order. In the late 1920 , Kelsen referred to his time as a transitional period in the history of international law, and saw this character reflected in the "contradictions of an international legal theory which in an almost tragic conflict aspires to the height of a universal legal community erected above the individual states but, at the same time, remains a captive of the sphere of power of the sovereign state."2 Almost forty years later, Wolfgang Friedmann arrived at a very similar conclusion when he said: "In terms of objectives, powers, legal structure and scope, the present state of international organisation presents an extremely complex picture. It reflects the state of a society that is both desperately clinging to the legal and political symbols of national sovereignty and being pushed towards the pursuit of common needs and goals that can be achieved only by a steadily intensifying degree of international organisation." What Kelsen described as a shortcoming of legal science - its inability to climb over the mental walls of the sovereign state - Friedmann extended to the state of the international order as such.

The contradictions Kelsen spoke of and the dilemma outlined by Friedmann are also, I think, characteristic features of this volume's theme - issues and perspectives of world constitutionalism. Sovereignty, which the two authors ad-

$1 \quad$ See Bardo Fassbender, "Sovereignty and Constitutionalism in International Law", in Neil Walker (ed.), Sovereignty in Transition (2003) 115, at 142.

2 See Hans Kelsen, Das Problem der Souveränität und die Theorie des Völkerrechts. Beitrag zu einer Reinen Rechtslehre (2 ${ }^{\text {nd }}$ ed. 1928), at 320.

3 See Wolfgang Friedmann, The Changing Structure of International Law (1964), at 293 et seq. 
dressed, and constitutionalism in international law are closely related issues. It was, in fact, Friedmann who first produced a sketch of international constitutional law as a "new field of international law."4 To speak, in our time, about the international constitutional order means approaching the same subject from the opposite side. But what, exactly, is that subject? In other words: What is, and to which ends do we study, international constitutional law?

That discipline is not to be confused with comparative constitutional law which recently has become the subject of a new journal. ${ }^{5}$ Instead, we are searching for a sub-discipline of public international law, namely the constitutional law of the international community which may be influenced by constitutional ideas and practices developed in a national context but stands on its own feet.

\section{Constitutional Arguments in International Law}

To use the notion of constitution in the context of public international law is today, it seems, much less problematic than it was five or, in any case, ten years ago. In an article published in 1998, I devoted substantial space to showing that there is no compelling reason to reserve the term constitution for the supreme law of a (sovereign) state ${ }^{6}$ but that, instead, the fundamental legal order of any autonomous community or body politic can be addressed as a constitution. ${ }^{7}$ With the words of Philip Allott, a scholar who has profoundly reflected on the meaning of constitutionalism in national societies and in the international society, "[a] constitution is a structure-system which is shared by all societies." ${ }^{\prime}$ This understanding entails a certain demystification of the institution of the (etatist) constitution and, with it, of the "sovereign state" as the former constitutional monopolist."

$4 \quad$ Ibid. at $152-159$.

5 See I. CON (Int'l J. Const'l L.), founded in 2003.

6 For a thoughtful analysis of the relationship of state and constitution, which reflects much of the great tradition of the German Staatslehre of the nineteenth and twentieth centuries, see Josef Isensee, "Staat und Verfassung", in Idem \& Paul Kirchhof (eds.), 2 Handbuch des Staatsrechts der Bundesrepublik Deutschland ( $3^{\text {rd }}$ ed. 2004), 3.

7 See Bardo Fassbender, "The United Nations Charter as Constitution of the International Community", 36 Col. J. Transnat'l L. (1998) 529, at 532-38, 555-61.

8 See Philip Allott, Eunomia: New Order for a New World (1990), at 164. See also Idem, "The Concept of International Law", in Michael Byers (ed.), The Role of Law in International Politics: Essays in International Relations and International Law (2000), at 72-76.

9 But see Dieter Grimm, "Ursprung und Wandel der Verfassung", in Isensee \& Kirchhof (eds.), 1 Handbuch des Staatsrechts der Bundesrepublik Deutschland ( $3^{\text {rd }}$ ed. 2003), 3, at 36 et seq. (arguing that the international order is characterized by a plurality of unconnected institutions and legal sources, and that there is so far, on the international level, no entity which could be constitutionalized ("kein konstitutionsfähiger Gegenstand")), and Ulrich Haltern, "Internationales Verfassungsrecht?", 128 Archiv des öffentlichen Rechts (2003) 511 (arguing that there is a fundamental difference between the "aestheticsymbolic meaning" of national law on the one hand, and European and international 
It is not entirely clear why in the meantime this transfer of the constitutional idea into the sphere of international law, which had had only few advocates, has become largely uncontroversial - many differences of opinion about how exactly such transfer should be understood or constructed notwithstanding. ${ }^{10}$

To some extent, the discussion about the future legal order of the European Union has contributed to that result. In the case of the EU, a gradual "constitutionalization" of a treaty-based order has been generally accepted. ${ }^{11}$ In the summer of 2003, the European Convention adopted by consensus the "Draft Treaty Establishing a Constitution for Europe ${ }^{\|_{12}}$ which in an amended version was signed by the Heads of State or Government of the EU member states on October 29, 2004 in Rome as the "Treaty Establishing the Constitution for Europe." If a text is officially called a "constitution", lawyers tend not to contradict. Some of the ideas developed in the context of European Community law were then carried over to the law of other organizations, especially the GATT and WTO. ${ }^{14}$ Secondly, it was understood that one can apply the notion of constitution in the realm of universal international law without necessarily being a proponent of a "world state", something which to many is still the epitome of horror. Also, and thirdly, as it happens, some writers jumped onto a wagon which appeared to be increasingly popular, content with

law on the other, leading to fundamentally different "imaginations of the political"). For reasons not to be discussed here, German legal culture has produced both the strongest supporters and opponents of the idea of a constitution beyond the nation-state.

For a recent review of the literature and a re-evaluation of issues like the traditional dichotomy between international and constitutional law (see Fassbender, supra note 7, at 532-538 and 555-561), "constitution" as a contested notion (ibid. at 553 et seq.) or the use of constitutional language (ibid. at 538 et seq.), see Thomas Cottier \& Maya Hertig, "The Prospects of $21^{\text {st }}$ Century Constitutionalism", 7 Max Planck UNYB (2004) 261.

Of the extensive literature, I only mention Jörg Gerkrath, Lémergence d'un droit constitutionnel pour l'Europe (1997); Ingolf Pernice, "Multilevel Constitutionalism and the Treaty of Amsterdam: European Constitution-Making Revisited", 36 Common Market Law Review 703 (1999); Christian Joerges, Das Recht im Prozess der Konstitutionalisierung Europas (EUI Working Paper LAW No. 2001/6); Anne Peters, Elemente einer Theorie der Verfassung Europas (2001); Neil Walker, "The EU and the WTO: Constitutionalism in a New Key", in G. de Burca and J. Scott (eds.), The EU and the WTO: Legal and Constitutional Issues (2001), at 31; Idem, "The Idea of Constitutional Pluralism", 65 Modern Law Review (2002) 317; Idem, "Postnational Constitutionalism and the Problem of Translation", in J.H.H. Weiler \& M. Wind (eds.), European Constitutionalism Beyond the State (2003), at 27; Bruno de Witte, "The Closest Thing to a Constitutional Conversation in Europe: The Semi-Permanent Treaty Revision Process", in Paul R. Beaumont et al. (eds.), Convergence and Divergence in European Public Law (2002), at 39.

See European Convention Doc. 850/03 of 18 July 2003.

For text, see Official Journal of the EU 2004/C 310 of 16 Dec. 2004.

14 See, in particular, Ernst-Ulrich Petersmann, Constitutional Functions and Constitutional Problems of International Economic Law (1991). For a critical discussion, see Armin von Bogdandy, "Law and Politics in the WTO-Strategies to Cope with a Deficient Relationship", 5 Max Planck UNYB (2001) 609, at 653-656. 
the general "progressive" ring of the words "constitution" and, especially, "constitutionalization". Or, to put it in a friendlier way: Those writers seized upon a notion which, albeit blurry, still seems to capture at least a great part of the fundamental changes in the international legal order which we all are sensing but cannot easily express in the language of (international) law we have learned..$^{15}$

However, this growing popularity of the use of the constitutional argument in international law has rather increased the terminological confusion. For instance, the different issues of a constitutionalization of the law of a particular intergovernmental organization or international regime on the one hand, and of the existence of a constitution of the international community as such, on the other, are often not sufficiently distinguished. ${ }^{16}$ Recent scholarship based on the work of Niklas Luhmann has argued against a "state-centered constitutionalism" (both on a national and an international level) and produced a new notion of "global civil constitutions" meant to express a "constitutionalization of a multiplicity of autonomous subsystems of world society."17 Such an inflationary use of the word "constitution" entails the danger of its devaluation. Not every increase in legal regulation, and not even every evolution of a hierarchical system of rules, equals a "constitutionalization." 18

A few years ago, I argued that the constitutional rhetoric I had analyzed was rarely based on a coherent idea of constitutionalism, and that only few writers had made an effort systematically to explain both the reasons and the consequences of the adoption of constitutional ideas. ${ }^{19}$ This situation has not changed much since. I identified three schools of thought to which such systematic efforts can be attributed: first the school founded by the Viennese jurist Alfred Verdross, ${ }^{20}$ who started out from Kelsen's legal theory but later both approached and influenced the mainstream,

15 For a systematic review of scholarly efforts to understand the changed international landscape, and for the place of the idea of "constitutionalization" in the current debate, see Armin von Bogdandy, "Demokratie, Globalisierung, Zukunft des Völkerrechts - eine Bestandsaufnahme", 63 Zeitschrift für ausländisches öffentliches Recht und Völkerrecht (2003) 853, at 864 et seq., 869 et seq.

16 But see Christian Walter, "Constitutionalizing (Inter)national Governance - Possibilities for and Limits to the Development of an International Constitutional Law", 44 German YB Int'l L. (2001) 170, at 191 et seq., who understands the statutes and basic rules of such organizations and regimes as Teilverfassungen, or "partial constitutions", of the international community.

17 See Gunther Teubner, "Globale Zivilverfassungen: Alternativen zur staatszentrierten Verfassungstheorie", ${ }_{3}$ Zeitschrift für ausländisches öffentliches Recht und Völkerrecht (2003) 1. See also Andreas Fischer-Lescano, "Die Emergenz der Globalverfassung", ibid. at 717.

18 See Grimm, supra note 9, at 4 and 7 .

19 See Fassbender, supra note 7, at 538. For a thoughtful recent re-examination, focusing on the constitutional character of the UN Charter, see Pierre-Marie Dupuy, "L'unité de l'ordre juridique international", Cours général de droit international public, $297 R d C$ (2002) 9, at 215-24.4, 286 et seq., 303-307.

2o See, in particular, Alfred Verdross, Die Verfassung der Völkerrechtsgemeinschaft (1926), and Alfred Verdross \& Bruno Simma, Universelles Völkerrecht: Theorie und Praxis ( $3^{\text {rd }}$ 
second (and partially influenced by the first) a group of scholars, led by the late judge of the ICJ Hermann Mosler, his successor Bruno Simma and Christian Tomuschat, advocating what I named the "doctrine of international community," ${ }^{21}$ and thirdly the New Haven School (or "policy-science approach") ${ }^{22}$ with Myres McDougal and Michael Reisman being the most prolific authors for the subject under discussion. Today, in the literature of international law, in particular the European, the second mentioned school, is by far the most influential one of the three. The term "the international community" has become commonplace, but more so in continental Europe than in Great Britain or the United States. ${ }^{23}$ (At the founding conference of the European Society of International Law in May 2004, Martti Koskenniemi critically discussed the international community school as an example of the European imagination of an international order modeled on European values and ideas: "We Europeans have one goal in common: International law shall be like we are.") ${ }^{24}$

A fourth approach, championed by Ernst-Ulrich Petersmann, insists on the need for integrating human rights into the law of the United Nations: "As long as international law and the UN Charter focus on state sovereignty without effective protection of human rights and without judicial safeguards against the frequent abuses of government powers and violations of the rule of law, it seems misleading to denote the UN Charter as the 'constitution' of 'the peoples of the United Nations." ${ }^{25}$ A related critique emphasizes the "democratic deficit", or lack of democratic participation, in international organizations. ${ }^{26}$

ed. 1984). See also Bruno Simma, "The Contribution of Alfred Verdross to the Theory of International Law", 6 EJL (1995) 33.

21 See, in particular, Hermann Mosler, "The International Society as a Legal Community", 140 $R d C(1974, \mathrm{IV}) 1$, revised version published as The International Society as a Legal Community (1980); Christian Tomuschat, "Obligations Arising for States Without or Against Their Will", 241 RdC (1993, IV) 195; Idem, "Die internationale Gemeinschaft", 33 Archiv des Völkerrechts (1995) 1; Bruno Simma, "From Bilateralism to Community Interest in International Law", $250 \mathrm{RdC}$ (1994-VI) 217.

22 See, in particular, Myres S. McDougal, Harold D. Lasswell and W. Michael Reisman, "The World Constitutive Process of Authoritative Decision", in Myres S. McDougal \& W. Michael Reisman, International Law Essays: A Supplement to International Law in Contemporary Perspective (1981) 191.

23 For respective writings see, in particular, Christian Tomuschat, "Die internationale Gemeinschaft", 33 Archiv des Völkerrechts (1995) 1, Daniel Thürer, "Recht der internationalen Gemeinschaft und Wandel der Staatlichkeit", in Idem et al. (eds.), Verfassungsrecht der Schweiz-Droit constitutionnel suisse (2001) 37, and Andreas L. Paulus, Die internationale Gemeinschaft im Völkerrecht (2001).

24 See Martti Koskenniemi, "International Law in Europe-Between Tradition and Renewal", Keynote Address at the ESIL Inaugural Conference, 14. May 2004.

25 See Ernst-Ulrich Petersmann, "Constitutionalism, International Law and We the Peoples of the United Nations", in Hans-Joachim Cremer et al. (eds.), Tradition und Weltoffenheit des Rechts: Festschrift für Helmut Steinberger (2002) 291, at 303.

26 See Hauke Brunkhorst, "Globalizing Democracy without a State", 31 Millenium-Journal of International Studies (2002) 675. 
Most recently, this array of approaches has been supplemented by an important contribution from political philosophy. Re-examining the Kantian vision of a world republic, Jürgen Habermas has outlined the structure of a "political constitution of a decentralized world society as a multi-level system of governance. ${ }^{{ }_{27}}$ Based on a dispassionate analysis of the present global situation, Habermas sees "a conceptual possibility of a political multi-level system which, as a whole, is not a state but nevertheless able to safeguard, without a world government, on a supranational level peace and human rights ... and to solve on a transnational level the many practical problems of 'global domestic politics' (Weltinnenpolitik). ${ }^{28} \mathrm{He}$ describes a "post-national constellation" of international affairs as supportive of a constitutionalization of public international $\operatorname{law}^{29}$ and agrees with this writer that in that process the UN Charter is of central importance..$^{30}$

\section{Different Constitutions: Fundamental Rules, Rules Not Based on State Consent, Jus Cogens}

In what seems to be the book that established the notion of constitution in international law, Alfred Verdross in 1926 used the word to describe "those norms which deal with the structure and subdivision of, and the distribution of spheres of jurisdiction in, a community."31 Accordingly, Verdross held that the constitution of the international legal community was composed of the fundamental rules and principles of international law determining its sources, subjects and application, and the jurisdiction allocated by that law to the individual states. Similarly, Christian Tomuschat said much later, in 1993: "Together with the rules on discharge of the executive and the judicial functions, the rules on law-making form the constitution of any system of governance. All these sets of prescriptions can be logically characterized as meta-rules, rules on how the bulk of other rules are produced, how they enter into force, how they are implemented and who, in case of differences over their interpretation and application, is empowered to settle an ensuing dispute."${ }^{32}$

27 See Jürgen Habermas, "Hat die Konstitutionalisierung des Völkerrechts noch eine Chance?" [Does the constitutionalization of international law still have a chance?], in Idem, Der gespaltene Westen (2004), 113, at 134. This translation and the following are provided by me, B.F.

28 Habermas, ibid. at 143 . See also ibid. at 159 et seq. For the possibility of a global constitution without a (global) state, see Fassbender, supra note 7, at 558: "Having untied the bond between state and constitution, one may also apply the term in the realm of universal international law without necessarily being a proponent of a 'world state'. An international constitution so understood is not bound to put an end to interstate relations based on international law."

See Habermas, supra note 27 , at 176.

See infra text accompanying note 56.

See Verdross, Die Verfassung der Völkerrechtsgemeinschaft, supra note 20, at v.

32 See Tomuschat, "Obligations", supra note 21, at 216. See also Allott, "The Concept of International Law", supra note 8, at 75 et seq.: "International constitutional law is what 
Clearly, this definition was influenced by H.L.A. Hart's distinction between "primary" and "secondary" rules, the latter being understood as "rules about rules." ${ }^{33}$

In that perspective, international constitutional law embodies rules of international law distinguished by their fundamental character. Those rules are either formal in nature (like the rules defining the subjects and sources of international law), or substantive (like the principle of sovereign equality of states, the principle of self-determination of peoples, or the ban on the use of force) ${ }^{34}$ The exact delimitation of a constitutional law so perceived varies from author to author. More or less, the respective rules belong to what, in analogy to the structure of civil codes like the German enacted in 1896, we could call the "general part" of international law. They address issues pertinent to the "foundation of the law of nations", as the first chapter of the introduction to Oppenheim-Lauterpacht's treatise was entitled, $^{35}$ as opposed to specific issues of, for instance, the law of the sea, the law of diplomatic relations, or environmental law.

However, what is the specific value of such a terminology? What does it tell us apart from what we all know by intuition - that some rules of international law are more important than others? Or does it mainly serve an instructive purpose, helping us to distinguish various types of rules and thereby better to understand the substance of the international law of our time?

Some authors do not stop here but emphasize, as the principal feature of international constitutional rules, their non-consensual character. Consider this statement by Professor Tomuschat: "States live, as from their birth, within a legal framework of a limited number of basic rules which determines their basic rights and obligations with or without their will .... One may call this framework ... the

some older writers called the 'necessary' law of nations. It contains the structural legal relations which are intrinsic to the coexistence of all kinds of subordinate societies. It confers on artificial legal persons, including the State-societies, the capacity to act as parties to international legal relations. ... The geographical and material distribution of constitutional authority among subordinate legal systems cannot finally be determined by those legal systems themselves, but only by a superordinate legal system, namely international constitutional law. ... International constitutional law determines the legal relationship of the subordinate public realms."

33 See H.L.A. Hart, The Concept of Law (1961), ch. V: "Law as the Union of Primary and Secondary Rules", at 92: "Thus they [the secondary rules] may all be said to be on a different level from the primary rules [of obligation], for they are all about such rules; in the sense that while primary rules are concerned with the actions that individuals must or must not do, these secondary rules are all concerned with the primary rules themselves. They specify the ways in which the primary rules may be conclusively ascertained, introduced, eliminated, varied, and the fact of their violation conclusively determined."

The principles in question are also being addressed as "the founding principles of the international legal order". See Christian Tomuschat, "International Law: Ensuring the Survival of Mankind on the Eve of a New Century", 281 RdC (1999) 9, at 161 et seq. 
constitution of the international community." ${ }^{36}$ According to that view, the international constitution is the entirety of those basic rules - whether formal or substantive - which every state is bound to observe irrespective of its own will. Those rules shall be distinguished from so-called "contingent" (i.e. accidental or nonessential) prescriptions that "in the same way as traffic rules on left-hand or right-hand driving, must be determined for the sake of legal clarity and avoiding disorder." ${ }^{37}$ In the case of "contingent" rules, state consent is said to be still the relevant basis of obligation, whereas constitutional prescriptions are determined by community interests which may allow for some degree of majoritarianism.

This concept borders on another which sees the rules of $j u s$ cogens (or peremptory norms of international law) as the heart of an international constitution - i.e., in the words of the Vienna Convention on the Law of Treaties, rules "accepted and recognized by the international community of States as a whole ... from which no derogation is permitted and which can be modified only by subsequent norm[s] of general international law having the same character."${ }^{18}$ Rules of jus cogens are "meta-rules" as described by Tomuschat. They are rules about rules because they control the admissibility and validity of rules states want to insert in a treaty concluded by them. At the same time, jus cogens rules are "higher law" (a feature characteristic of national constitutional law in comparison with other, "ordinary" law) because they place certain norms beyond the reach of states when states, bilaterally or multilaterally, exercise their law-making function. In that sense, Antonio Cassese noted that with jus cogens "a body of supreme or 'constitutional' principles was created." ${ }^{39}$

It is well known that in recent years the concept of jus cogens has gained importance in fields other than the law of treaties, in particular in international criminal law, ${ }^{40}$ the law of sovereign immunity of states and state officials, ${ }^{41}$ the determination of universal criminal jurisdiction ${ }^{42}$ and the law of state responsibility. ${ }^{43}$ Switzerland is the first country which has incorporated the concept into its constitutional law. Articles 193 and 194 of the revised Swiss Federal Constitution of 1999 provide that amendments to the Constitution may not violate peremptory norms of international law.

36 See Tomuschat, "Obligations", supra note 21, at 211 (emphasis added).

37 Ibid. at 286. - Similarly, Allott, "The Concept of International Law", supra note 8, at 75, distinguished between "international constitutional law" and "international public law".

39 See Antonio Cassese, International Law (2001), at 141.

40 Ibid. at 141,144 et seq.

41 Ibid. at 145. See also Oliver Dörr, "Staatliche Immunität auf dem Rückzug?", 41 Archiv des Völkerrechts (2003) 201, at 214 et seq.

42 lbid.

43 See arts. 26, 40, 41 and 50 of the ILC Draft Articles on the Responsibility of States for Internationally Wrongful Acts of July 26, 2001, UN Doc. A/CN.4/L.602/Rev.1. 
The jus cogens perspective of international constitutional law is particularly value-oriented because all the rules presently recognized as jus cogens (in the first place, the prohibitions of genocide, aggression, slavery and of trading in human beings, and the right of peoples to self-determination) are substantive in nature and have a human rights dimension, the latter mainly accounting for the use the International Criminal Tribunals for the former Yugoslavia and for Rwanda have made of jus cogens arguments. ${ }^{44}$ Jus cogens, one could say, is a sort of Decalogue of a secularized world, a minimal code of behaviour that can be condensed into one rule: Thou shalt not do other human beings terrible wrongs! While this decalogue is in accordance with contemporary "Western" values, the criticism that it is only reflecting such values is unfounded. It was after all the developing countries and the socialist states who advocated the concept of jus cogens against the opposition or skepticism of the West.45

There is a partial substantive identity of jus cogens and obligations erga omnes which, as is well known, the ICJ described as obligations "towards the international community as a whole." 46 The category of obligations erga omnes was advanced to give states who, according to traditional international law, were not affected by a certain breach of rules, "a legal interest in their protection." 47 This way, pivotal community values should be safeguarded in the absence of effective community organs. The Court gave a number of examples of such obligations erga omnes, including the prohibition of acts of aggression and genocide, "the principles and rules concerning the basic rights of the human person, including protection from slavery and discrimination," ${ }^{48}$ and the right of self-determination. ${ }^{49} \mathrm{~A}$ related third concept, "international crimes of states", which once had been supported by the ILC, ${ }^{50}$ was

44 See Bardo Fassbender, "Der Schutz der Menschenrechte als zentraler Inhalt des völkerrechtlichen Gemeinwohls", 30 Europäische Grundrechte Zeitschrift (2003) 1, at 5 et seq.

45 See Cassese, supra note 39, at 139.

46 See Barcelona Traction, 1970 IC) Reports 3, at 32, paras. 33-34, and East Timor (Portugal v. Australia), 1995 ICJ Reports 90, at 102, para. 29. See also art. 48, para. 1(b), and art. 54 of the ILC Draft Articles, supra note 43.

47 See Barcelona Traction, 1970 IC) Reports at 32, para. 33.

48 Ibid., para. 34.

49 See East Timor, supra note 46, para. 29.

5o Art. 19(2) of the draft articles on state responsibility (part 1) adopted by the ILC on first reading on July 25,1980 , defined an "international crime" as follows: "An internationally wrongful act which results from the breach by a State of an international obligation so essential for the protection of fundamental interests of the international community that its breach is recognized as a crime by that community as a whole constitutes an international crime." Report of the ILC, UN General Assembly Official Records, Supp. No. 10, UN Doc. A/35/10 (1980); 2 ILC Y.B. (1980), pt. 2, 30, 32. For discussion, see Joseph H.H. Weiler et al. (eds), International Crimes of States: A Critical Analysis of the ILC's Draft Article 19 on State Responsibility (1989), and André de Hoogh, Obligations Erga Omnes and International Crimes: $A$ Theoretical Inquiry into the Implementation and Enforcement of the International Responsibility of States (1996). 
eventually abandoned by the Commission when it accepted the proposals of its special rapporteur Professor James Crawford..$^{51}$

What do the different approaches I mentioned have in common? The international constitutionalism supported by them is, one can say, a "progressive" movement - "progressive" in the sense the UN Charter speaks of the "progressive development of international law" (Art. 13(1a)) - which aims at fostering international cooperation by consolidating the substantive legal ties between states as well as the organizational structures built in the past. The idea of a constitution in, or of, international law is summoned as an abbreviation for an increasingly differentiated and hierarchical law, and as a symbol of a (political) unity which eventually shall be realized on a global scale. This implies that he or she who is basically satisfied with the present state of affairs or who insists on preserving the independence of the individual state vis-à-vis the international community as much as possible has no reason to refer to the notion of an international constitution..$^{52}$

The relative success of the "international community school" is understandable because this school (unlike, for instance, the New Haven approach) stays within the limits of "mainstream" legal thought. Rooted in positivism and determined not to lose touch with actual state practice, but at the same time cautiously idealistic, it seeks to develop the international legal system towards greater cohesion and effectiveness. This tension causes a certain doctrinal improvisation that cannot satisfy those looking for a clear and convincing theoretical foundation upon which the concept of an international constitution could rest. The contents of a constitutional law as a part of international law remain indistinct, and so do the legal consequences, if there are any, of characterizing a rule as a constitutional rule. In particular, the supremacy of international constitutional law in a hierarchy of norms of international law is only a vague concept. Indeed, for the authors of the "international community school" the symbolic value of the constitutional terminology prevails, "constitution" implying the high degree of interdependence and integration of peoples and states which is regarded as a reality or, at least, a necessity.

Perhaps this indistinct and vague character of what is addressed as international constitutional law is a true representation of the law as it stands. In that case, international constitutional law would essentially belong to an international law of the future, with only certain beginnings and forerunners being discernible in our time.

\section{The UN Charter as Constitution of the International Community}

In my own work, I have tried to give the idea of an international constitutional law a clearer and more concrete meaning by closely associating it with the United $\mathrm{Na}$ tions Charter. Drawing especially on the writings of Verdross, I suggested that the Charter, although it was formally created as a treaty, is characterized by a consti-

51 For an analysis of the 2001 draft articles by the special rapporteur, see James Crawford, The International Law Commission's Articles on State Responsibility: Introduction, Text and Commentaries (2002).

52 The last sentences have partly been taken from my 1998 article, supra note 7 , at 552. 
tutional quality which in the course of the last fifty years has been confirmed and strengthened in such a way that today the instrument must be referred to as the constitution of the international community. ${ }^{53}$ I argued that the Charter shows a number of strong constitutional features. ${ }^{54}$ In particular, the Charter includes rules about how the basic functions of governance are performed in the international community, that is to say, how and by whom the law is made and applied, and how and by whom legal claims are adjudicated. ${ }^{55}$ The Charter also establishes a hierarchy of norms (Article 103). I further tried to demonstrate that by understanding the Charter as a constitution we gain a standard allowing adequate (legal) solutions of issues such as the interpretation of the Charter, the relationship between its law and "general international law", the reform of the UN Security Council, or the question to what extent the Security Council is bound by international law.

In his recent book The Divided West, Jürgen Habermas has taken up this analytical effort by identifying three "normative innovations" which primarily provide the UN Charter with a constitutional quality and make it possible to interpret the Charter as a global constitution: (1) the explicit combination of the goal of safeguarding world peace and a human rights policy, (2) the connection of the prohibition of the use of force with a realistic threat of sanctions and criminal prosecution, and (3) the inclusiveness of the United Nations and the universality of UN law. ${ }^{56}$ Habermas concluded that the UN Charter "is a framework in which UN member states no longer must understand themselves exclusively as subjects bringing forth international treaties; they rather can now perceive themselves, together with their citizens, as the constituent parts of a politically constituted world society. ${ }^{57}$

Today, the outstanding importance of the UN Charter in the international legal order is generally accepted in legal literature. As R.St.J. Macdonald already remarked in 1988, "the majority of international lawyers would probably classify the Charter as something more than a treaty yet less than a world constitution."58 Recently Pierre-Marie Dupuy called the Charter "un traité sans equivalent", "un acte

53 See $i b i d$. at 531 et seq.

54 See ibid. at 573-84. For a similar analysis with much the same results, see Thomas $M$. Franck, "Is the U.N. Charter a Constitution?", in Jochen A. Frowein et al. (eds), Negotiating for Peace: Liber Amicorum Tono Eitel (2003), 95. Franck concluded: "Perpetuity, indelibleness, primacy, and institutional autochthony: these four characteristics of the U.N. Charter relate that unique treaty more proximately to a constitution than to an ordinary contractual normative arrangement" (ibid. at 102).

55 For an exposition of the "main functions of governance" of the international community, see Tomuschat, supra note 34, part III (pp. 305-433).

56 See Habermas, supra note 27 , at 159.

57 Ibid. ("Nach meiner Auffassung stellt die UN-Charta einen Rahmen bereit, worin sich die Mitgliedstaaten nicht länger nur als Subjekte völkerrechtlicher Verträge verstehen müssen; zusammen mit ihren Bürgern können sie sich nun als die konstituierenden Träger einer politisch verfassten Weltgesellschaft erkennen.")

58 See R. St. J. Macdonald, "The Charter of the United Nations and the Development of Fundamental Principles of International Law", in Bin Cheng \& E. D. Brown (eds.), Con- 
fondateur, constitutif d'un nouvel ordre international." 59 Also, almost all authors who use constitutional language refer in one way or another to the Charter. There is a tradition in political speech and legal writing of speaking of the Charter as a constitution. Consider, for instance, the following quotation from Lord McNair's Law of Treaties of 1961: "[T] he Charter ... is the nearest approach to legislation by the whole community of States that has yet been realised. Our submission is that those of its provisions which purport to create legal rights and duties possess a constitutive or semi-legislative character, with the result that member States cannot 'contract out of' them or derogate from them by treaties made between them, and that any treaty whereby they attempted to produce this effect would be void."6o This statement draws our attention to the problem of the legal consequences of attributing to the Charter a constitutional quality. In that respect, Lord McNair did not go beyond what is expressly provided for in Article 103 of the Charter. He did not suggest, as in fact I do, that the Charter is the supporting frame of all international law and the highest layer in a hierarchy of norms of international law leaving no room for a category of "general international law" existing independently beside the Charter. ${ }^{61}$

A principal reason for my suggesting that the UN Charter must be understood as the constitution of the international community was the intention to get out of the fog of the indistinct constitutional rhetoric by turning to one visible document as an authoritative statement of the fundamental rights and responsibilities of the members of the international community and the values to which this community is committed, as well as the basis of the most important community institutions. ${ }^{62}$ I pointed out that there is no irreconcilable contradiction between the idea of such a written constitution and that of a more inclusive constitutional process. I also did not overlook the shortcomings of the Charter as a constitution, in particular its limitations with respect to a definition of the rights of the individual, and the concomitant necessity to see the Charter together with other customary and treaty law of a fundamental nature which I called the "constitutional by-laws" of the international community ${ }^{63}$ Further, I tried to explain that addressing the UN Charter as a constitution does not mean to equate the Charter with a state constitution like that of the United States of America or the French Republic, but that instead the constitutional idea in international law must be understood as an autonomous concept rather than an extrapolation of the constitutional law of a particular state..$^{64}$ At the same time, an

temporary Problems of International Law: Essays in Honour of Georg Schwarzenberger on his Eightieth Birthday (1988), 196, at 197.

59 See Dupuy, supra note 19, at 217.

60 See Lord Arnold D. McNair, Law of Treaties (1961), at 217. See also I. Brownlie, "The United Nations Charter and the Use of Force, 1945-1985", in Antonio Cassese (ed.), The Current Legal Regulation of the Use of Force (1986), 491, at 495.

61 See Fassbender, supra note 7, at 585.

62 See ibid. at 616 et seq.

63 See ibid. at 588 et seq.

64 See ibid. at 572. 
established notion like "constitution" is malleable only up to a certain degree; it cannot be extended or adapted at will. Since the American and the French Revolution, and notwithstanding the English exception, Western political thinking associates that notion not only with a system of fundamental principles according to which a state is governed but also with the document embodying these principles. Therefore, it is doubtful whether a concept of a fragmented international constitution - a constitution not unified by a central text like the UN Charter - has a chance of success.

One may add that a certain gap between constitutional rules and constitutional reality is not unusual in the case of state constitutions too. For that reason, the argument that, for instance, the Security Council actually has not played the role provided for in the Charter, or the Economic and Social Council did not become the center of international economic and social cooperation envisaged by Chapters IX and X of the Charter, is not refuting the Charter's constitutional quality.

Lastly, it is a profound misunderstanding to equate the advancement of the constitutional idea in international law with a weakening of the institution of the independent state. To assume the existence of a constitution of the international community does not mean to put the state in new, more restraining chains of law. On the contrary, it is that constitution which protects the legal authority and autonomy of every state against unlawful interventions by other states and international organizations, similar to the protection of the fundamental rights and freedoms afforded to individual citizens by a state constitution..$^{65}$ It is the constitution of the international community which safeguards the entitlement of a state, and the people constituting it, to autonomous development and self-responsibility within the limits set by international law.

However, so far most legal scholars favouring the idea of international constitutionalism prefer to stay in conceptually vaguer worlds. Some of them seem to suffer a sort of reality shock when encountering a United Nations so far away from their ideals of pure theory. Others, while acknowledging the necessity of a steadily intensifying degree of international organisation, remain captives of a legal training based on the cornerstone of the "sovereign state." In the legal map of the world that is on their minds they cannot find a proper place for a global constitution. This is also the reason for the comparative attractiveness of $j u s$ cogens. In its quality as customary international law it can easily be fit into the traditional system of sources of international law and, what is more important, the traditional idea of international law as a system of rules based on the consent of states. Accordingly, Charter law is ranked below jus cogens ${ }^{66}$ - as if those peremptory norms, all of which are based on rules and values of the Charter, could survive without the Charter. The true relationship between the UN Charter and jus cogens is turned on its head. ${ }^{67}$ Besides,

65 See Fassbender, supra note 1, at 128 et seq.

66 See Application of the Convention on the Prevention and Punishment of the Crime of Genocide (Bosnia \& Herzegovina v. Yugoslavia (Serbia \& Montenegro)), 1993 ICJ Reports 407, at 440 para. 100 (E. Lauterpacht, J., separate opinion). For critical discussion, see Fassbender, supra note 7 , at 589 et seq.

67 See also Dupuy, supra note 19 , at 307 . 
as Professor Cassese has reminded us, "the fact remains that, at the level of State to State relations, peremptory norms have largely remained a potentiality." ${ }^{\prime 6}$

But the hesitancies to give the UN Charter a central place in a constitutional structure of the international community are also politically motivated. At the beginning of the twenty-first century, the position and role of the United Nations in international affairs find themselves under great stress. ${ }^{69}$ In turbulent times, the organization faces an environment which is partly openly hostile, partly disinterested, and partly friendly but not decisively supportive. Fundamental rules of the Charter, such as the ban on the use of force, are challenged, ${ }^{\circ}$ and the legitimacy of the Security Council, as the organization's institutional backbone, is called into question. And yet, and in my opinion deplorably, the members of the international community are far away from uniting their strength in an effort to give new life and vigor to the Charter system of international governance. ${ }^{71}$ To many, the Charter looks more and more like a monument of a distant past - an embodiment of an idea of collective security whose days are over. In this situation, can one dare to regard the Charter as the foundation of the entire house of contemporary international law?

Philip Allott once remarked: "Failing to recognize itself as a society, international society has not known that it has a constitution." ${ }^{22}$ The future of the constitutional understanding and effectiveness of the UN Charter - which is, I suggest, tantamount to the foreseeable future of constitutionalism in international law in general - will not depend on the interpretive and constructive efforts of legal science but on the fate of the United Nations itself. Only a strong political move, comparable to the founding of the UN in the constitutional moment of 1944-45, could reaffirm the Charter's claim to be the constitution of the international community. Perhaps the UN era is drawing to a close, ${ }^{73}$ and only now, looking back, the peoples of the United Nations realize that they had a constitution. But the idea of a constitution of the international community will survive because it is both indispensable as a legal device and unrivalled as a symbol of unity of humankind realizing its existence in one world. If the future landscape of international relations

68 See Cassese, supra note 39, at 147.

69 For an analysis of "anti-constitutionalist trends" in international law, see Anne Peters, "Global Constitutionalism Revisited" (2004) (on file with author).

$70 \quad$ See Bardo Fassbender, "Die Gegenwartskrise des völkerrechtlichen Gewaltverbotes vor dem Hintergrund der geschichtlichen Entwicklung", 31 Europäische GrundrechteZeitschrift (2004) 241.

71 See Bardo Fassbender, "All Illusions Shattered? Looking Back on a Decade of Failed Attempts to Reform the UN Security Council", 7 Max Planck UNYB (2003) 183.

72 See Allott, supra note 4 , at 418.

73 For a description of possible alternatives to a constitutionalization of international law as a continuation of the "Kantian project," see Habermas, supra note 27 , at 178 et seq. As such alternatives, the author identifies (1) a US "hegemonic liberalism," (2) a "neoliberal global market society" with marginalized states, (3) a "postmarxist scenario of a scattered imperial rule without a capital," and (4) a global Grossraumordnung based on the ideas of Carl Schmitt. 
will know a legal order at all, as an order based on the principles of self-determination, autonomy and equality of all nations, a universal constitution will be an essential element of that order. And just as much as the idea of a constitution of the international community will survive, the contribution the UN Charter has made to this idea's development will be unextinguishable in the book of world history. As Jürgen Habermas said, "the League of Nations and the United Nations are great, even though risky and reversible, achievements on the arduous way to a political constitution of world society." ${ }^{74}$

74 See Habermas, supra note 27 , at 145. 